Abstracta Iranica Abstracta Iranica

Revue bibliographique pour le domaine irano-aryen

Volume 30 | 2010

Comptes rendus des publications de 2007

\title{
« Nekotorye itogi arheologičeskih issledovanij na Staroj Nise ». Rossijskaja Arheologija, n. 1, 2007, pp. 150-158.
}

\section{Carlo Lippolis}

\section{(2) OpenEdition}

Journals

Édition électronique

URL : http://journals.openedition.org/abstractairanica/37598

DOI : 10.4000/abstractairanica.37598

ISSN : 1961-960X

Éditeur :

CNRS (UMR 7528 Mondes iraniens et indiens), Éditions de l'IFRI

\section{Édition imprimée}

Date de publication : 8 avril 2010

ISSN : 0240-8910

\section{Référence électronique}

Carlo Lippolis, « « Nekotorye itogi arheologičeskih issledovanij na Staroj Nise ». Rossijskaja Arheologija, n. 1, 2007, pp. 150-158. », Abstracta Iranica [En ligne], Volume 30 | 2010, document 46, mis en ligne le 08 avril 2010, consulté le 30 septembre 2020. URL : http://journals.openedition.org/abstractairanica/ 37598 ; DOI : https://doi.org/10.4000/abstractairanica.37598

Ce document a été généré automatiquement le 30 septembre 2020.

Tous droits réservés 


\section{« Nekotorye itogi arheologičeskih issledovanij na Staroj Nise ». Rossijskaja Arheologija, n. 1, 2007, pp. 150-158.}

\section{Carlo Lippolis}

1 The article concerns the destination and main chronology of Old Nisa, according to the data gathered especially by the Soviet and Russian expeditions in the central complex (but there are also some notes about the recent Italian-Turkmen works). In Pilipko's opinion, the centre was probably founded as a royal fortified residence around the middle of the IInd century B.C.; after a while, probably after the death of its founder Mithridates I, Old Nisa changed its function and became a dynastic cult centre for the Arsacids. A third phase of utilization is documented by the restoration of some of the main buildings in the central part of the citadel, while the late phases of the site still remain uncertain. Following the results of his last works in Nisa, still in progress (2008), the author seems not to exclude the presence of an inner chamber inside the massif of the Tower-building and therefore a new and more punctual interpretation of the building itself.

\section{INDEX}

Thèmes : 3.1. Est de l'Iran 
AUTEURS

CARLO LIPPOLIS

Università di Torino 